\title{
Impact of Education on Fertility: Evidence from a Tribal Society in Assam, India
}

\author{
Amarjyoti Mahanta \\ Department of Economics, Dibrugarh University, Dibrugarh, India \\ Correspondence should be addressed to Amarjyoti Mahanta; amarjyoti@dibru.ac.in
}

Received 27 April 2016; Revised 7 September 2016; Accepted 26 October 2016

Academic Editor: Sally Guttmacher

Copyright ( 2016 Amarjyoti Mahanta. This is an open access article distributed under the Creative Commons Attribution License, which permits unrestricted use, distribution, and reproduction in any medium, provided the original work is properly cited.

\begin{abstract}
This paper examines the education-fertility linkage in tribal society through a cross section study on the Misings, the second largest scheduled tribe of the state of Assam, India. Applying multiple regression analysis, the paper finds that while the education of both wife and husband has retarding effect on fertility, the number of live births born is significantly less when wives are more educated than husbands. The education of females has been found to have positive relation with fertility up to 5.3 years of schooling and negative relation thereafter so as to reach the replacement level of fertility at the graduate level of education. Thus, the critical years of education of the wives required to have a depressing impact on fertility is 5.3. The paper recommends policies for expansion of education with primary focus on inclusion and retention of the females in education.
\end{abstract}

\section{Introduction}

The relationship between fertility and education has been widely investigated in population science research. Descriptions upon the causal relationship between the numerical expansion in the population size through birth and the qualitative development of the population through education have been made in both theoretical and empirical observations. A strong effect of education on fertility reduction has been found in the empirical research on tribal population $[1,2]$ and nontribal populations of India [3-5]. Yet some studies have not found any significant impact of education on fertility [6].

As fertility involves two parents, an analysis of fertility behaviour at household level should take into account the characteristics of both the spouses. The fact that the educational status of the husband and wife has fertility depressing effect to varied extent has been reported by past studies in India and abroad [3, 4, 6-11]. Analyzing data for India, Drèze and Murthi [4] have found that female literacy has significant negative impact on fertility, while male literacy makes no contribution to fertility reduction, after controlling for female literacy. A study by Hirschman and Rindfuss [7] observed significant relationship between higher level of education of the women with the timing of first birth. Corijn et al. [8] have observed that high level of education of the female partner leads to the postponement of first childbirth, but high level of education of the male partner does not. A study by Akin [9] found that female education in primary and secondary level has significant negative impact, but male education in primary and secondary level has significant positive impact on fertility. The reason for male's behaviour is said to be the son preference and concerns of the continuity for family names.

Examining the impact of female education on fertility in eleven countries, Jain observed that in some cases the association between female education and marital fertility is curvilinear, indicating an increase in marital fertility with a small increase in female education [10]. It suggests that depressing effect of education on fertility can be expected beyond a threshold level of education. About the threshold level of education, Pillai [11] has found that first four years of schooling of the wife increases completed family size, while beyond four years of education reduces family size.

There is no dearth of literature on sociological and anthropological aspects of the tribes of India [12-19]. But the study on the demographic behaviour of the Indian tribes, particularly of the tribes of Northeastern region of India, is limited. Though few demographic studies on the Indian 
tribes [6, 20-25] have been made, the impact of education on fertility has not been examined in greater detail. This paper attempts to further stress the issue of education-fertility linkage in tribal societies through a cross section study on the Misings of Assam.

The Mising is the second largest scheduled tribe of the Indian state of Assam with a total population of 6.80 lakhs which accounted for 17.52 percent of the total scheduled tribe population of the state in 2011. Census data of India show that Mising population registered a decadal growth rate of 52.87 percent during 1991-2001. But, in the next decade, the Mising population grew at a rate (15.84 percent) lower than the growth rate of the state (17.07 percent) and national (17.64 percent) population. The fertility rate, represented by the total fertility rate, among the Misings (2.5 children per woman) is found to be higher than that of the national and state levels ( 2.3 children per woman, Sample Registration System, 2013). The concentration of the Misings is mostly seen in the districts of Brahmaputra valley of Assam. Being settled mostly in the river valley areas, the modern amenities of health and education are not easily available to them. Therefore, an enquiry into the impact of education on their fertility is undertaken. The paper tries to deal with the following questions:

(1) Does education play significant role in the determination of the fertility level of the tribal women?

(2) Is the education of the mother more important than the education of the father for fertility reduction?

(3) What should be the critical years of education that would have depressing impact on fertility?

\section{Theoretical Context}

Education can influence fertility indirectly through its impact on some other factors that influence fertility directly. Davis and Blake [26] called these factors "intermediate variables" in their fertility model. Later, Bongaarts [27] referred to the direct fertility influencing factors as "proximate determinants." Bongaarts' study found that variations in four factors, namely, marriage, contraception, lactation, and induced abortion, are the primary proximate causes of fertility differences among populations. While identifying the impact of socioeconomic factors on fertility, these variables must also be considered as they show the paths through which socioeconomic factors influence fertility. This paper, therefore, investigates the impact of education on fertility, taking three proximate determinants of fertility, namely, female age at marriage, use of contraceptive, and length of breast-feeding, together with education in the same multivariate set-up.

Marriage is a cultural variable and the age at marriage is influenced by cultural values. In most of the societies, marriage marks the onset of exposure to conception. Lower age at marriage of the tribal women has been reported by several studies (e.g., $[1,24,25]$ ). Early female age at marriage increases the duration of effective married life lived and hence raises the probability of having more children. Such inverse relation between female age at marriage and fertility has been found in tribal societies [6, 25, 28]. Education may affect fertility by influencing the age at marriage. More educated individuals who invest their energy in obtaining more education are likely to marry later and to invest more in occupational and other activities [29].

Though studies in India have reported fertility restraining impact of contraception [30-32], the prevalence of contraceptive among few tribes of India has been documented to be less $[1,2,21]$. Education may influence female's fertility decision through high contraceptive usages [33]. The educated people are more informed about contraception and their attitude to family planning is more positive [34]. Higher education leads to more adoption of contraceptives by increasing exposure to information and ideas disseminated through printed material [10].

Breast-feeding, on the other hand, determines the period of postpartum amenorrhea. Prolonged breast-feeding protects against pregnancy by delaying the normal ovulation [35]. Protracted breast-feeding increases the duration of postpartum amenorrhea [30]. The longer a woman breast-feeds, the longer she will remain infecund [36]. Education may also influence fertility by influencing breast-feeding behaviour. Highly educated women have greater propensity to breastfeed which may be due to the differences in advice from the medical community, social support from family and friends, accessibility to progressive infant care literature, and voluntary organizations [37].

Education, thus, may influence the level of fertility by bringing in qualitative development in persona which may be manifested in delayed entry into marriage, delayed parenthood, and spacing of births through high contraceptive usages and higher propensity to breast-feeding. Therefore, it is theorized that education has retarding effect on fertility.

\section{Data and Methodology}

The data for the study have been collected through a multistage sampling design. Three districts of Assam having the highest proportion of the Mising population of the state, namely, Dhemaji, Lakhimpur, and Jorhat, have been taken as the sample districts. One subdivision having the highest proportion of the Mising population of each of the sample districts has been taken as sample subdivision. From the three sample subdivisions, 23 Mising villages are taken as sample villages. In the last stage of the sampling frame, 880 Mising households from the sample villages are selected as sample households following a simple random sampling technique. One married woman of the reproductive age group of each of the sample households was interviewed in the presence of the husband using a structured questionnaire. The samples were informed about the academic purpose behind the collection of data and the strict confidential nature of the information revealed. Having obtained the consent, sociodemographic information from the 880 respondents was collected in 2008 .

To deal with the objectives of the paper, three linear multiple regression models have been set. In each model, the number of live births ever born (LBEB) to the respondents has been taken as the dependent variable. The LBEB is defined as the number of children born alive to the sample women 
in the entire reproductive life. The births have been found to have occurred within the current marriage of the couples. In all the models, the independent variables are the same except the variable representing education.

The first model is used to examine whether education plays significant role in the determination of the fertility level of the tribal women or not. The model traces the independent impact of the wives and husbands on fertility by considering two independent variables for education (measured in terms of the number of years completed in schooling) of the sample wives and husbands along with female age at marriage, contraceptive use, and length of breast-feeding. The second model is run to examine whether the education of wife or the husband is more important in affecting fertility by adding a dummy independent variable for education of the parents. The last model is used to find out the "critical year of education" that one must complete to have inhibiting impact on fertility. The details of the regression models are shown in Table 1.

Additionally, one-way ANOVA and independent sample $t$-test have been used to investigate the statistical difference between the levels of fertility of different clusters of the selected independent variables. Furthermore, a binary logit model is also used to identify the effect of years of education of wives and husbands on the practice of contraceptives to substantiate the argument made in the paper.

\section{Results and Discussion}

The mean number of live births ever born to the sample couples has been found to be 2.95. Table 2 shows the descriptive statistics of the live births ever born against the selected independent variables. The fact that the age at marriage in India is lower in general and among the scheduled tribes in particular is stated by the National Family Health Survey-III, which finds that the median age at marriage of scheduled tribe women in the age group of $20-49$ is 16.5 years against the overall national average of 17.2 years. The observed mean age at marriage of the Mising females (19.17 years) is higher than that of the scheduled tribe women of India (16.5 years, NFHS-III) but is lower than the mean age at marriage of females in Assam (20.8 years) and in India as a whole (19.8 years, District Level Household and Facility Survey-III). Table 2 shows that the fertility level indicated by the mean number of live births ever born is the highest for the early married Mising women and has declined with the increase in age of the females at marriage. In order to know whether or not the difference between the means of number of live births ever experienced by the females of different age groups is statistically significant, analysis of variance (ANOVA) is made. With F-value (i.e., 15.29) being significant at 0.01 level, it can be said that the difference among the means is statistically significant. Likewise, the mean number of live births ever born has declined with the increase in the duration of breast-feeding. The one-way ANOVA $(F=63.39 ; p<0.01)$ suggests that the difference among the mean number of live births of the women of different breast-feeding duration groups is statistically significant.
The practice of contraceptive among the sample couples is observed to be less as only 41.93 percent of the couples have ever used any modern method of family planning. Few other studies $[1,2,21]$ have also reported poor use of contraceptives among the Indian tribes. So far as the practice of contraceptive devices is concerned, this study finds that 45.53 percent of the users of contraceptives have used condom and 30.08 percent have used oral pills, while 5.42 percent have used both. But the percentage of users choosing the permanent method, that is, sterilization, is found to be less (18.97 percent). The study also finds that the number of live births ever born to the ever users of contraceptive (i.e., 2.04) is less than that of the nonusers (i.e., 3.61). The statistical difference between the two means is verified through an independent sample $t$-test. The results show that the difference in the mean number of live births ever born to the users and to the nonusers of contraceptive is significant at 0.01 level.

The literacy rate among the scheduled tribe population of India is reported to be low. As per the population census of India 2011, the literacy rate of the scheduled tribe population of India (59 percent) is much lower than that of the total national population (74 percent). However, the scheduled tribe population of Assam witnessed 72.1 percent literacy rate, which was higher than the national average (59 percent). The present study finds lower literacy rate (65.1 percent) among the Misings compared to that of the total scheduled tribe population of the state (72.1 percent). Moreover, the study finds that 34.66 percent of the sample wives and 31.48 percent of the husbands are illiterate. Bivariate classification in Table 2 shows that the mean number of live births ever born falls with the increase in the years of education of the wives and husbands. The one-way ANOVA also confirms that the difference among the means of the education groups of both wives and husbands is statistically significant. Furthermore, the level of fertility is less in those families where the wives are more educated than the husbands, while it is the highest when both wife and husband are illiterate. The ANOVA results prove that the difference in means is statistically significant at 0.01 level.

The bivariate analysis, thus, shows that the level of fertility varies significantly across different groups of age at marriage of the females, duration of breast-feeding, users and nonusers of contraceptives, and years of education of wives and husbands. In order to make more accurate predictions on the variations in the level of fertility caused by selected educational variables, they are taken together with the other independent variables in multivariate regression framework. The succeeding analysis has addressed the research questions one after another.

The first research question taken in the study is whether or not education significantly determines the fertility level of the tribal women. The answer to the research question is provided through the multivariable linear regression model 1. $F$-statistic of the model (Table 3), being significant at 1 percent level, establishes that the independent variables sufficiently explain the variations in the dependent variable. Moreover, the variance inflating factor for the regressors ranged between 
TABLE 1: Independent variables of the regression models and their unit of measurement.

\begin{tabular}{|c|c|c|}
\hline $\begin{array}{l}\text { Model } \\
\text { number }\end{array}$ & Independent variables (with label) & Unit of measurement \\
\hline \multirow{5}{*}{1} & (i) Female age at marriage (AM) & (i) In years \\
\hline & (ii) Contraceptive use (CU) & (ii) Dummy variable $(1=$ users; $0=$ nonusers $)$ \\
\hline & (iii) Duration of breast-feeding (BF) & (iii) In months \\
\hline & (iv) Education of the wife (EW) & (iv) Years of schooling completed \\
\hline & (v) Education of the husband (EH) & (v) Years of schooling completed \\
\hline \multirow{4}{*}{2} & (i) Female age at marriage (AM) & (i) In years \\
\hline & (ii) Contraceptive use (CU) & (ii) Dummy variable ( $1=$ users; $0=$ nonusers $)$ \\
\hline & (iii) Duration of breast-feeding (BF) & (iii) In months \\
\hline & (iv) Education of the parents (EP) & $\begin{array}{l}\text { (iv) Dummy variable }(1=\text { wife is more educated than husband; } 0=\text { husband is } \\
\text { equally educated to or more educated than the wife) }\end{array}$ \\
\hline \multirow{6}{*}{3} & (i) Female age at marriage (AM) & (i) In years \\
\hline & (ii) Contraceptive use $(\mathrm{CU})$ & (ii) Dummy variable ( $1=$ users; $0=$ nonusers $)$ \\
\hline & (iii) Duration of breast-feeding (BF) & (iii) In months \\
\hline & (iv) Education of the wife (EW) & (iv) Years of schooling completed \\
\hline & (v) Square of education of the wife (SEW) & (v) Square of years of schooling completed \\
\hline & (vi) Education of the husband (EH) & (vi) Years of schooling completed \\
\hline
\end{tabular}

Dependent variable: live births ever born (LBEB).

TABLE 2: Mean live births ever born (LBEB) by selected independent variables.

\begin{tabular}{|c|c|c|c|c|}
\hline Variables & Number of observations & Mean LBEB & Std. deviation & $F$-value \\
\hline \multicolumn{5}{|l|}{ Female age at marriage (in years) } \\
\hline Up to 18 & $428(48.64)$ & 3.26 & 1.62 & \multirow{4}{*}{$15.29(p<0.01)$} \\
\hline 19 to 21 & $291(33.07)$ & 2.81 & 1.38 & \\
\hline 22 to 24 & $125(14.20)$ & 2.46 & 1.41 & \\
\hline 25 and above & $36(4.09)$ & 2.11 & 1.21 & \\
\hline \multicolumn{5}{|l|}{ Duration of breast-feeding } \\
\hline Up to 18 months & $295(33.52)$ & 3.67 & 2.06 & \multirow{3}{*}{$63.39(p<0.01)$} \\
\hline 19 to 24 months & $273(31.02)$ & 2.85 & 1.11 & \\
\hline 25 and above months & $312(35.45)$ & 2.37 & 0.86 & \\
\hline \multicolumn{5}{|l|}{ Contraceptive use } \\
\hline Users & $369(41.93)$ & 2.04 & 0.86 & \multirow[t]{2}{*}{$18.81^{*}(p<0.01)$} \\
\hline Nonusers & $511(58.07)$ & 3.61 & 1.58 & \\
\hline \multicolumn{5}{|l|}{ Education of the wives } \\
\hline No education & $305(34.66)$ & 3.37 & 1.22 & \multirow{4}{*}{$23.54(p<0.01)$} \\
\hline Up to 5 years & $175(19.89)$ & 3.27 & 2.22 & \\
\hline $6-10$ years & $278(31.59)$ & 2.53 & 1.24 & \\
\hline More than 10 years & $122(13.86)$ & 2.43 & 1.24 & \\
\hline \multicolumn{5}{|l|}{ Education of the husbands } \\
\hline No education & $277(31.48)$ & 3.62 & 1.37 & \multirow{4}{*}{$29.09(p<0.01)$} \\
\hline Up to 5 years & $40(4.55)$ & 3.05 & 2.31 & \\
\hline $6-10$ years & $276(31.36)$ & 2.66 & 1.43 & \\
\hline More than 10 years & $287(32.61)$ & 2.57 & 1.44 & \\
\hline \multicolumn{5}{|l|}{ Education of the parents } \\
\hline Wife is more educated & $77(8.75)$ & 2.42 & 1.45 & \multirow{3}{*}{$31.10(p<0.01)$} \\
\hline Husband is equally or more educated & $577(65.57)$ & 2.76 & 1.59 & \\
\hline Both illiterate & $226(25.68)$ & 3.60 & 1.20 & \\
\hline
\end{tabular}

Total number of observations: 880 .

${ }^{*} t$-statistic.

Figures within brackets represent percentage in total. 
TABLE 3: Significance of education of wives, education of husbands, and other variables in explaining fertility (regression model 1).

\begin{tabular}{lccc}
\hline Regressor & $B$ & $t$ & VIF \\
\hline Constant & 6.464 & $18.648^{* *}$ & \\
Female age at marriage & -0.111 & $-6.718^{* *}$ & 1.017 \\
Duration of breast-feeding & -0.025 & $-4.110^{* *}$ & 1.029 \\
Contraceptive use ( $1=$ users & & & \\
of contraceptives; $0=$ & -1.289 & $-13.305^{* *}$ & 1.243 \\
nonusers of contraceptives) & & $-2.327^{* *}$ & 1.476 \\
Education of the wives & -0.025 & $-1.905^{*}$ & 1.508 \\
Education of the husbands & -0.019 & \\
\hline \multicolumn{4}{c}{$R^{2}=0.32 ; F=81.171^{* *} ;$ d.f. $=5 ; N=880$} \\
${ }^{* *} p<0.01 ;{ }^{*} p<0.05$.
\end{tabular}

1.01 and 1.50, which rules out the presence of multicollinearity in the regression model.

The results of regression model 1 (Table 3 ) establish that education plays a significant role in the determination of the fertility level of the tribal women. In the model, the regression coefficients for education of both husbands and wives are found to be significant, with negative signs implying the retarding impact of education on fertility. Results show that as the number of years of schooling of the wives and husbands increases by one year, the number of live births decreases by 0.025 and 0.019 , respectively. The negative impact of education on fertility may be due to its association with the age at marriage, particularly of the women. In this study, the number of years of schooling of the sample wives and their age at marriage are found to be significantly positively correlated at 0.01 level of significance. It implies that the age at marriage goes up with the increase in years spent in education, because education interferes with marriage. Delayed entry into marriage, in turn, reduces fertility significantly by shortening the duration of effective married life within which a woman is exposed to fertility.

The negative impact of education on fertility may also be due to high contraceptive prevalence among the educated people [10, 33, 38]. The educated people have better knowledge on family planning and have favourable attitude towards family planning, which results in higher adoption of contraceptives. To test whether education affects the practice of contraceptives or not, a binary logistic regression model is fitted. In the logistic regression model, use of contraceptive is taken as the dummy dependent variable coding 0 for the nonusers and 1 for the users of contraceptive. The completed years of education of the wives and the husbands have been taken as the independent variables. The regression results (Table 4) show that the number of years spent on education by wives and husbands has significant positive impact on the use of contraceptive. The exponential of the regression coefficient for years of education of the wife shows that as the number of years of education of the wife increases by one year, the odds in favour of using contraceptives increase by 24 percent. Likewise, with the increase in the number of years of education of the husband by one year, the odds in favour of using contraceptives increase by 7 percent. Practice of
TABLE 4: Impact of years of education on the use of contraceptives (logistic regression results).

\begin{tabular}{lccc}
\hline Dependent variable & $\begin{array}{c}\text { Independent } \\
\text { variables }\end{array}$ & $\beta$ & $\operatorname{Exp}(\beta)$ \\
\hline $\begin{array}{l}\text { Years of } \\
\text { education of } \\
\text { the wife }\end{array}$ & $0.218^{*}$ & 1.243 \\
$\begin{array}{l}\text { of contraceptive use }(1=\text { users } \\
\text { nonusers of contraceptives) }\end{array}$ & $\begin{array}{l}\text { Years of } \\
\text { education of } \\
\text { the husbands }\end{array}$ & $0.070^{*}$ & 1.073 \\
\hline
\end{tabular}

Cox and Snell's $R^{2}=0.29$; Nagelkerke's $R^{2}=0.39$.

Hosmer and Lemeshow goodness of fit test statistic $=8.507(p=0.203)$. ${ }^{*} p<0.01$.

contraceptive, in turn, reduces fertility significantly, which is established in all the three linear regression models.

The second research question of the study is whether the education of the mother is more important than the education of the father for fertility reduction. Regression model 2 is used for probing the research question which finds education of the mother to be more important than that of the father (Table 5). The regression coefficient for education of the parents illustrates that the number of live births ever born is 0.018 lower when the wives are more educated than the husbands. The reason for this may be the fact that the risk of pregnancy entirely and that of child rearing mostly is taken by the females. The educated females can make their husbands realize the reproductive health risks and economic costs caused by high fertility and can convince their husbands of fertility control. Moreover, husband also appreciates the opinion of the wife when she is more educated.

As the education of the wives is found to be more important than that of the husbands, an attempt has been made at identifying the critical years of education of the wives, which is more likely to bring down fertility. For this purpose, the method used by Pillai [11] has been used. To gauge the nonlinear impact of the education of the wives on fertility, square of years of schooling of the wives have been added to regression model 1 . The outcomes of resultant regression model 3 shown in Table 6 depict that all the variables including the three variables standing for education are significant at 0.01 level of significance. The critical years of education of the wives have been worked out by varying the years of education of the wives and assigning the mean values to the other variables in the regression results of model 3. The critical years of education of the wives required to have depressing impact on fertility are found to be 5.3. In other words, fertility increases with the increase in the years of schooling up to 5.3 years, declines thereafter, and reaches the replacement level when wives are educated up to the graduate level (i.e., 15 years). This supports Bongaarts' [39] conclusion that women with primary education tend to have higher fertility than those with secondary-plus education. The results indicate that decline in fertility can be expected only when the women are educated above the primary level. This is because of the fact that in order to inculcate low fertility values one must have few years of education. The reason for the association of graduate level education with 
TABLE 5: Significance of education of parents and other variables in explaining fertility (regression model 2).

\begin{tabular}{|c|c|c|c|}
\hline Regressor & $B$ & $t$ & VIF \\
\hline Constant & 6.303 & $18.257^{*}$ & \\
\hline Female age at marriage & -0.114 & $-6.819^{*}$ & 1.014 \\
\hline Duration of breast-feeding & -0.025 & $-3.976^{*}$ & 1.033 \\
\hline $\begin{array}{l}\text { Contraceptive use }(1=\text { users of contraceptives; } 0=\text { nonusers of } \\
\text { contraceptives })\end{array}$ & -1.451 & $-16.248^{*}$ & 1.036 \\
\hline $\begin{array}{l}\text { Education of the parents }(1=\text { wife is more educated than husband; } 0= \\
\text { husband is equally educated to or more educated than the wife })\end{array}$ & -0.018 & $-0.145^{*}$ & 1.010 \\
\hline
\end{tabular}

$$
R^{2}=0.30 ; F=95.430^{*} ; \text { d.f. }=4 ; N=654
$$

${ }^{*} p<0.01$.

TABLE 6: Significance of education and other variables in explaining fertility (regression model 3).

\begin{tabular}{lcc}
\hline Regressor & $B$ & $t$ \\
\hline Constant & 6.196 & $17.820^{*}$ \\
Female age at marriage & -0.101 & $-6.126^{*}$ \\
Duration of breast-feeding & -0.025 & $-4.097^{*}$ \\
Contraceptive use $(1=$ users of & & \\
contraceptives; $0=$ nonusers of & -1.221 & $-12.602^{*}$ \\
contraceptives) & & \\
Education of the wives & 0.126 & $3.622^{*}$ \\
Square of education of the wives & -0.012 & $-4.584^{*}$ \\
Education of the husbands & -0.037 & $-3.437^{*}$ \\
\hline \multicolumn{2}{c}{$R^{2}=0.33 ; F=72.693^{*} ;$ d.f. $=6 ; N=880$} \\
\hline${ }^{*} p<0.01$.
\end{tabular}

the replacement level of fertility may be the fact that graduate level education increases the likelihood of the work participation of the women in organized activities, which conflicts with childbearing.

\section{Conclusion}

The study finds that education is a significant determinant of the fertility level even in a tribal society. While the education of both wife and husband has retarding effect on fertility, the number of live births born is significantly less when wives are more educated than husbands. The education of the females has positive relation with fertility up to 5.3 years of schooling and negative relation thereafter. The replacement level of fertility is achieved when females are educated to the graduate level. It can be recommended that policies for expansion of education with primary focus on inclusion and retention of the females in education should be taken. The recommendation is justified also on the ground that the mean of years of schooling of the sample wives (i.e., 5.12 years) is less than the critical years of schooling required to have fertility limiting impact.

\section{Competing Interests}

The author declares that there are no competing interests.

\section{References}

[1] R. Borah, Demographic Profile of the Adis, Department of Economics, Dibrugarh University, Dibrugarh, India, 2005.

[2] K. C. Borah, Ed., The Singphos: A Demographic Profile, Department of Economics, Dibrugarh University, Dibrugarh, India, 2006.

[3] H. Kaur, "Impact of income and education on fertility," The Journal of Family Welfare, vol. 46, no. 1, pp. 70-76, 2000.

[4] J. Drèze and M. Murthi, "Fertility, education, and development: evidence from India," Population and Development Review, vol. 27, no. 1, pp. 33-63, 2001.

[5] M. Mubarak and A. Mahanta, "Determinants of rural fertility: evidence from dibrugarh district of assam," The International Journal of Humanities \& Social Studies, vol. 2, no. 8, pp. 103-110, 2014.

[6] R. Mutharayappa, "Factors affecting fertility among tribals," Man and Development, vol. 16, no. 4, pp. 63-79, 1994.

[7] C. Hirschman and R. Rindfuss, "Social, cultural, and economic determinants of age at birth of first child in peninsular Malaysia," Population Studies, vol. 34, no. 3, pp. 507-518, 1980.

[8] M. Corijn, A. C. Liefbroer, and J. J. Gierveld, "It takes two to tango, doesn't it? The influence of couple characteristics on the timing of the birth of the first child," Journal of Marriage and Family, vol. 58, no. 1, pp. 117-126, 1996.

[9] M. S. Akin, "Education and fertility: a panel data analysis for middle eastern countries," The Journal of Developing Areas, vol. 39, no. 1, pp. 55-69, 2005.

[10] A. K. Jain, "The effect of female education on fertility: a simple explanation," Demography, vol. 18, no. 4, pp. 577-595, 1981.

[11] V. K. Pillai, "Wife's education and urban family size in India: the form of the relationship," Sociological Focus, vol. 14, no. 3, pp. 247-253, 1981.

[12] V. Pakyntein, "Gender preference in khasi society: an evaluation of tradition, change and continuity," Indian Anthropologist, vol. 30, no. 1-2, pp. 27-35, 2000.

[13] S. Toppo, "Aging and the aged in the Tribal cultures," Indian Anthropologist, vol. 30, no. 1-2, pp. 65-71, 2000.

[14] J. Mipun, The Mishings (Miris) of Assam, Development of a New Life Style, Gyan Publishing House, New Delhi, India, 2000.

[15] R. Singh and A. Palta, "Foods and beverages consumed by abujhmarias-a primitive tribe of bastar in chhattisgarh," Tribal Health Bulletin, vol. 10, no. 1-2, 2004.

[16] A. Mishra and S. Sarma, "Understanding Health and Illness among tribal communities in Orissa," Indian Anthropologist, vol. 41, no. 1, pp. 1-16, 2011. 
[17] S. Sengupta, "Health status of tribal women in north east india: a review," Indian Journal of Physical Anthropology \& Human Genetics, vol. 29, no. 1-2, pp. 141-150, 2010.

[18] G. K. Rout and N. Priyadarshani, "School community symbiosis: a case study in rural tribal orissa," Indian Journal of Social Development, vol. 11, no. 2, pp. 463-475, 2011.

[19] C. Sarmah and K. Deuri, "Blood pressure among the adult deuri women of lakhimpur district, assam," Indian Journal of Physical Anthropology \& Human Genetics, vol. 33, no. 1, pp. 99-108, 2014.

[20] S. Basu and G. K. Kshatriya, "Fertility and mortality trends in the Kharia Tribals of Orissa," Social Change, vol. 27, no. 1, pp. 114-128, 1997.

[21] A. K. Kapoor and G. K. Kshatriya, "Fertility and mortality differentials among selected tribal population groups of northwestern and eastern India," Journal of Biosocial Science, vol. 32, no. 2, pp. 253-264, 2000.

[22] A. Maharatna, "Tribal fertility in India: socio-cultural influences on demographic behaviour," Economic and Political Weekly, vol. 35, no. 34, pp. 3037-3047, 2000.

[23] G. D. Pandey and R. S. Tiwary, "Some aspects of population growth of the primitive tribes of madhya pradesh," The Journal of Family Welfare, vol. 46, no. 2, pp. 66-72, 2000.

[24] R. K. Biswas and A. K. Kapoor, "Fertility profile of a primitive tribe, Madhya Pradesh," Anthropologist, vol. 5, no. 3, pp. 161-167, 2003.

[25] S. Nanda, "Cultural determinants of human fertility: a study of tribal population in Orissa," Anthropologist, vol. 7, no. 3, pp. 221227, 2005.

[26] K. Davis and J. Blake, "Social structure and fertility: an analytic framework," Economic Development and Cultural Change, vol. 4, no. 3, pp. 211-235, 1956.

[27] J. Bongaarts, "A framework for analyzing the proximate determinants of fertility," Population and Development Review, vol. 4, no. 1, pp. 105-132, 1978.

[28] R. Khongsdier, "Fertility and mortality differentials among the War Khasis of Meghalaya," in Tribal Studies in North East India, S. Sengupta, Ed., pp. 147-159, Mittal Publications, New Delhi, India, 2002.

[29] M. M. Marini, "Effects of the timing of marriage and first birth on fertility," Journal of Marriage and Family, vol. 43, no. 1, pp. 27-46, 1981.

[30] L. Visaria, "Proximate determinants of fertility in India: an exploration of NFHS data," Economic and Political Weekly, vol. 34, pp. 3033-3040, 1999.

[31] R. G. Amonker and G. Brinker, "Reducing fertility in India," International Journal of Sociology of the Family, vol. 33, no. 2, pp. 327-348, 2007.

[32] P. Arokiasamy, "Fertility decline in India: contributions by uneducated women using contraception," Economic and Political Weekly, vol. 44, no. 30, pp. 55-64, 2009.

[33] T. C. Martin and F. Juarez, "The impact of women's education on fertility in latin america: searching for explanations," International Family Planning Perspectives, vol. 21, no. 2, pp. 52-80, 1995.

[34] M. Potgieter, "Factors influencing contraceptive use by groups in the post-transitional stages of development," Southern African Journal of Demography, vol. 6, no. 1, pp. 57-63, 1996.

[35] J. Knodel, "Breast feeding and population growth," Science, vol. 198, no. 4322, pp. 1111-1115, 1977.

[36] M. Chaudhry, "Role of the social and cultural factors in human fertility in India," Population and Environment, vol. 12, no. 2, pp. 117-137, 1990.
[37] C. Hirschman and M. Butler, "Trends and differentials in breast feeding: an update," Demography, vol. 18, no. 1, pp. 39-54, 1981.

[38] A. Mahanta and H. Goswami, "Family planning among the tea garden labour community of assam: a study on level and determinants of ever use of contraceptives," Journal of Family Welfare, vol. 60, no. 1, pp. 74-82, 2014.

[39] J. Bongaarts, "Completing the fertility transition in the developing world: the role of educational differences and fertility preferences," Population Studies, vol. 57, no. 3, pp. 321-335, 2003. 


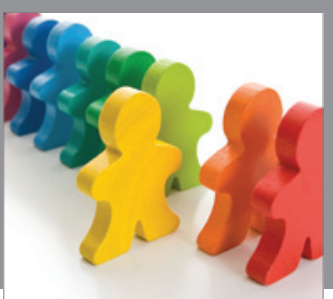

Autism

Research and Treatment
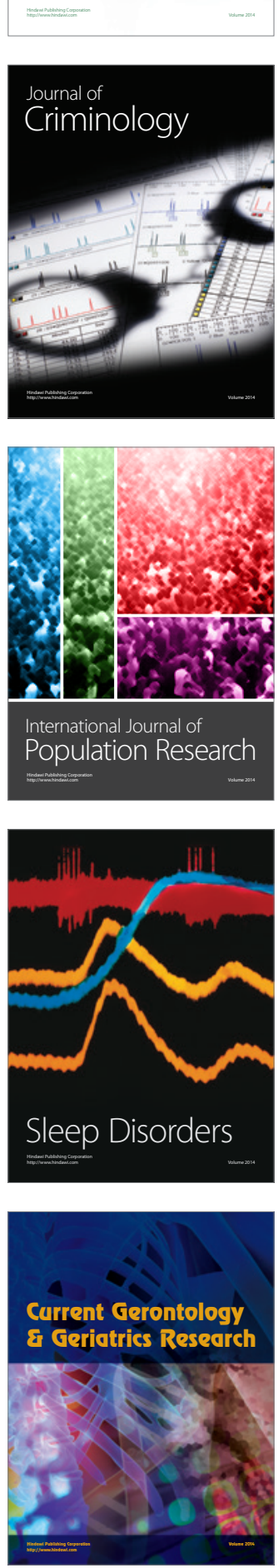

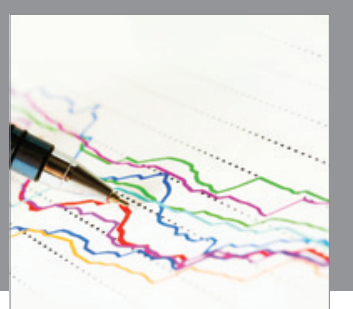

Economics

Research International
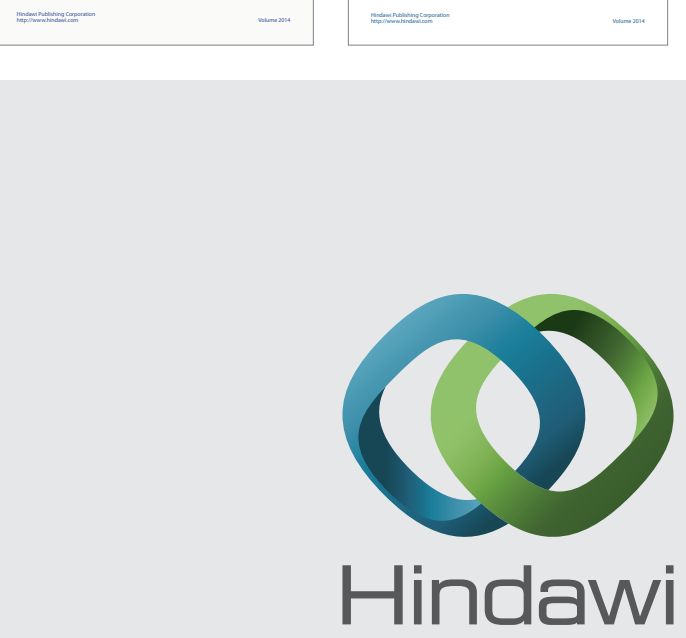

Submit your manuscripts at

http://www.hindawi.com
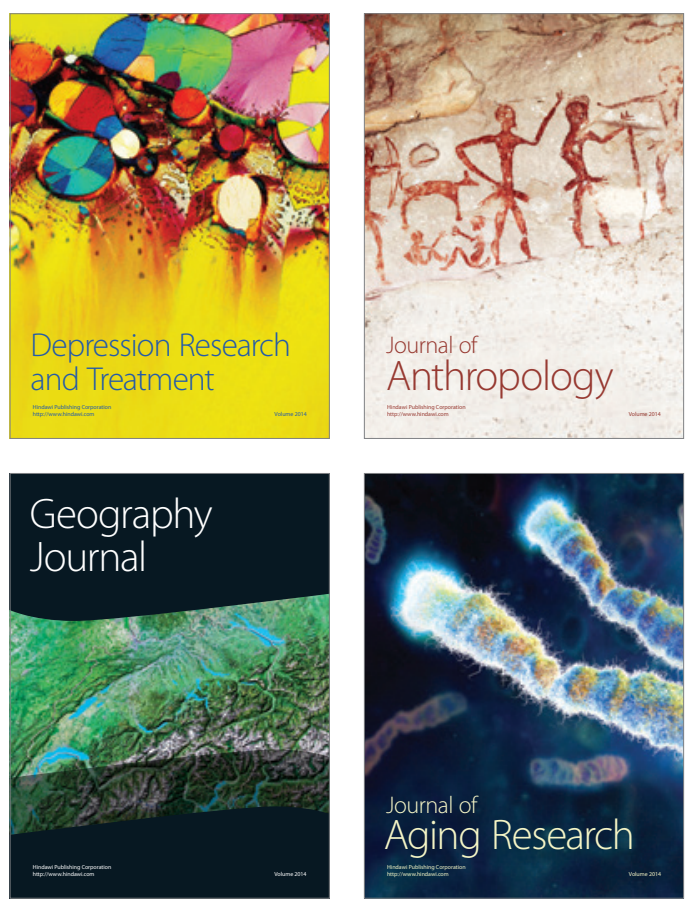
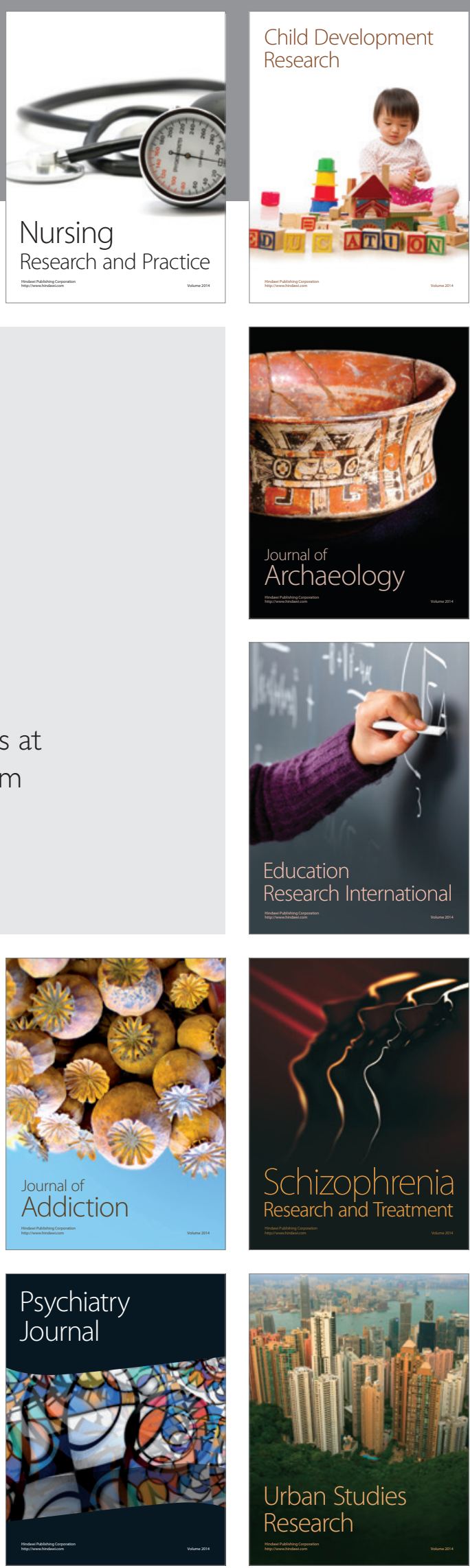